Fomicheva, N.M. (2021). Garden chair restoration. Scientific view on the modern problems of cultural heritage and arts in the context of social development. Klironomy, 1 (1), 84-109. Hlučín-Bobrovníky: "Anisiia Tomanek" OSVČ. Фомичёва, Н.М. (2021). Реставрация садового стула. Scientific view on the modern problems of cultural heritage and arts in the context of social development. Klironomy, 1 (1), 84-109. Hlučín-Bobrovníky: "Anisiia Tomanek" OSVČ.

DOI: $10.47451 /$ her2021-04-003

EOI: $10.11249 /$ her2021-04-003

The paper is published in Crossref, Internet Archive, Google Scholar, Academic Resource Index ResearchBib, JGate, ISI, CiteFactor, ICI, eLibrary databases.

Natalia M. Fomicheva

Artist-restorer of gilding of the highest category

Restorer of DAA works, art critic, art expert

Honorary Restorer of Saint Petersburg

Honored Worker of Culture of the Russian Federation

St Petersburg, Russia

E-mail: natalif47@yandex.ru

\title{
Garden chair restoration
}

\section{Abstract:}

The article is devoted to the realization of unique practical methods of restoration of decorative and applied art objects, which is a significant work in cultural heritage preservation because the topic is practically inexhaustible, both for researchers, art historians and for restorers-performers. The subject of the study was household garden gilded furniture of Russia of the 19th century. The project aimed to return the garden chair to the exhibition form for further use in the museum halls, as an object of 19th-century garden furniture art. To understand the restoration problems of the kind of furniture, the author of the article turned to the researchers' publications devoted to the aspects of the creation, decoration and restoration of 19th-century furniture. The author presents in detail the stages of furniture restoration. As well as the technologies used for this type of restoration work. As a result of the comprehensive restoration of the garden chair with rattan, the master restorer acquired a certain useful theoretical knowledge of the topic and practical experience of working with the decorative and applied art subject, which had only characteristic features of its technical condition and methods of working to return the chair to its aesthetic and exposition appearance. The materials presented in the article will be useful for practising restorers and novice young professionals.

Keywords: 19th-century garden gilded furniture, glossy and matt gilding, gilding imitation with Dutch metal, tinting, decorative coatings' protection from oxidation.

Наталия Михаймовна Фомичева

художник-реставратор позолоты высшей категории

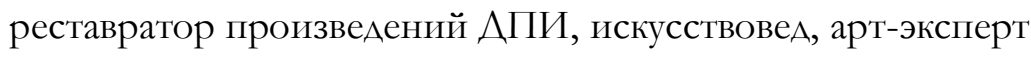


почётный реставратор Санкт-Петербурга заслуженный работник культуры РФ

Санкт-Петербург, Россия

E-mail: natalif47@yandex.ru

\title{
Реставрация садового стума
}

\begin{abstract}
Aннотачия:
Статья посвящена реализации уникальных практических методов реставрации предметов Аекоративно-прикцаАного искусства, которая является важной работой в сфере сохранения культурного наследия в связи с тем, что эта тема практически неисчерпаема, как Аля исследователей, искусствоведов, так и Аля реставраторов-исполнителей. Предмет исследования являлась бытовая садовая золочёная мебель России XIX века. Цель проекта было возвращение садовому стулу экспозиционного вида Аля Аальнейшего использования его в за^ах музея, как предмета садового мебельного искусства XIX века. А^я понимания проблем реставрации Аанного предмета мебели автор статьи обратился к публикациям исследователей, посвящённым аспектам создания, отАелки и реставрации мебели XIX века. Автором подробно представлены этапы реставрации мебели. А также технологии, применяемые Аля Аанного виАа восстановительных работ. В результате проведённой комплексной реставрации садового стула с ротангом мастером-реставратором был приобретён определённый полезный теоретический багаж знаний по теме и практический опыт работы с предметом декоративно-прикладного искусства, имевшего характерные только Аля него особенности технического состояния и методы работы с ним по возвращению стулу эстетического и экспозиционного виАа. Материалы, изложенная в статье, будут полезны Аля практикующих реставраторов и начинающих молодых специалистов.
\end{abstract}

Ключевые слова: садовая золочёная мебель XIX века, глянцевое и матовое золочение, имитация позолоты поталью, тонирование, защита декоративных покрытий от окисления.

\section{Introduction}

Restoration of objects of decorative and applied art is an important work in the field of cultural heritage preservation because the topic is almost inexhaustible, both for researchers, art historians and for restorers-performers. In the expositions and collections of various museums, an enormous number of pieces of furniture of different styles and eras are stored. Many of them have lived a long and not always safe life for their safety. Some items came to museums from private collections or were received by museums as extortionate property after the death of private owners.

The use of furniture items in everyday life was not always correct concerning the finish, often high-quality in the manufacture, but suffered as a result of the lack 
of careful attitude to it when using. Often these items were subjected to unprofessional 'restoration', which consisted of applying bronze paintwork. To perform this 'restoration', the owners took a bronze powder, diluted it with the first varnish that came to hand, the resulting composition was casually applied to the surface of worn places, or in general, a solid thick layer was painted over everything in a row, thereby distorting the once neatly executed original author's finish of the object.

When entering the restoration workshop, the subject was comprehensively examined by the master first visually, and its detailed photo-fixation was made, both of general types and of its characteristic defects, which were subsequently corrected by the master restorer himself or with his associates, restorers of other professions. If there were any questions about the technological plan, analytical studies of the soils and finishing layers, both historical and post-construction, were carried out to select restoration materials and select the restoration methods necessary in this case through the correct experimental work.

The subject of the study is household garden gilded furniture of 19th-century Russia.

The project purpose is to return the garden chair to its display form for further use in the museum halls, as an object of 19th-century garden furniture art.

Project objectives:

- conduct a comprehensive study of a piece of furniture of the 19th century with the definition of its style and purpose of use;

- identify the technologies used on the piece of furniture in its manufacture,

- determine the materials of the historical decoration of the object,

- identify new construction materials that have appeared as a result of the use or operation of the item,

- conduct experimental work to develop a methodology for the conservation and restoration of the object,

- carry out the conservation and restoration of the object, according to the compiled methodology.

The theoretical research consists of the study of analogue objects and the technology of their manufacture and decoration based on historical literary sources and familiarization with the restoration documentation related to the conservation and restoration of similar pieces of furniture with the same historical finish as the one obtained for restoration. 
To understand the problems of furniture restoration, the author of the article turned to the researchers' publications devoted to the aspects of the creation, decoration and restoration of 19th-century furniture. Among the sources of information, the general role was played by Daniel Alcouf's work Restoration of Furniture in translation from the French language. In this book, there are many recipes and technologies for finishing furniture, which is necessary for performing a sequence of restoration operations and applying finishing materials. The necessary book in every restorer work is Chemistry in Restoration by the authors M.K. Nikitin and E.P. Melnikova, published in 1990 in Leningrad and still very popular among restorers of many professions related to museum restoration. The collection of the course of lectures Restoration Materials, edited by T.S. Fedoseeva and published in Moscow in the Indrik publishing house in 2016, was useful, too. The book of the senior researcher of the State Hermitage T.M. Sokolova Ornament-the Handwriting of the Epoch, published in 1992 in the Aurora publishing house helps the restorer in establishing and clarifying the style of the work based on the characteristic features of the subject of restoration. Styles of Furniture by D. Kes, published in Budapest in 1979 by the Hungarian Academy of Sciences publishing house, is a kind of encyclopedia that allows restorers to find answers to many questions when attributing museum exhibits. A great help in the work of the gilt restorer is provided by professional publications on the subject of the work performed: Gilding, Silvering and Bronzing on Wood by L.P. Schmidt, printed in 1903 in Moscow in N.N. Bulgakov's printing house. Similar in name and content is V.A. Antsov's publication, which is a practical guide for carpenters, furniture and frame makers, also released in Moscow in 1911. One of the most popular books on gilding, which gives answers to many questions, is A.S. Nikolaev's book Works of the Gilder published in 1947. It describes in detail both the technological processes and the classification of restoration materials used for gilding on various base materials, which are different, is widely presented. A more modest section on the execution of gilding in A.Y. Revo's book Painting and Artistic and Decorative Works (Moscow, 1947) still gives irreplaceable tips for a modern master restorer on gilding on poliment, offers a Leningrad recipe for this composition and the working technology with it on works of decorative and applied art. The joint work of S.I. Vanin and S.E. Vanina Technique of Furniture Artistic Finishing, published in 1940, gives an idea of the many options for finishing furniture that can meet the restorer in the course of his practical work, to help the master in solving many questions that arise in the work. From the professional literature of the past years, it should mention the 19th-century publications Gilding 
and Silvering of Wooden Products by two different authors V. Lermontov and K.A. Kaznacheyev, published in St Petersburg in 1890 in the series Craft Newspaper.

\section{Introduction of the master to the subject of restoration}

A few years ago, I was offered to restore a garden chair with rattan on the seat, which was in the museum's collections. The purpose of the restoration was to return it to the exposition view. The restoration task was to restore the decorative decoration of the 19th-century monument of the in the author's manner. As time and work have shown, this has not become an easy task.

According to the laws of the genre, before the immediate restoration, it was necessary to carefully study the object, and the methods to finish it, fix it in photographs and describe its technical state of preservation. At the first cursory acquaintance with the subject of restoration, perhaps, its features were not very noticeable to those who wrote the task, but after all, they were keepers, and, consequently, art historians, furniture specialists. This fact was surprised when the look of the chair from all sides before starting work started.

This item was sent to the gilt restoration workshop after the restoration of the joiner's base. An inspection of the monument revealed that the chair had previously been assembled from five scattered fragments of other chairs. It was quite obvious, both in the style of execution of individual elements and in the technology of their decorative finishing, made according to levkas of different thicknesses in two different gilding techniques and even with imitation gilding with Dutch metal. All the details of the chair after assembly did not coincide with each other in the places of joiner's interfaces in shape and pattern in height and width by $2-3 \mathrm{~cm}$. It was evidenced by the traces of old glues, traces of the endings of the soils, their finishes, and the round-shaped holes that appeared during the restoration of the base on the back of the chair in the area of the frame on the backside for additional strengthening of the structure with wooden treenails. The back of the chair with its back legs was alien to this piece of furniture.

On the front side of the back, on the element of a bow, there was previously combined gilding on the poliment in combination with matte gilding. It was evidenced by the trace remains of gilding in the recesses of the relief and the almost white-washed ground under the glossy gilding - a red-brown poliment.

The backside of the chair back in the upper part was made in the technique of gilding imitation by Dutch metal on the applied layer of gulfarba (a multicomponent composition for performing matte gilding). This thick layer of 'gulfarba' was previously damaged by a metal object, clearly when trying to remove 
this binder (with a scalpel), and the layer of Dutch metals turned green from oxidation from time to time. The imitation of gilding with Dutch metal on the back of the chair on the backside in the bow area is a clear late intervention since initially this type of combination of different finishes does not happen in a genuine monument with expensive gilding on the poliment, originally made on the front side.

The upper part of the chair back was badly worn. It also previously had a finish in the form of imitation gilt Dutch metal. On it and the sides of the back, there were traces of sweat decomposition from oxidation as a result of the harsh operation of the object. The side raised sides of the chair back are badly worn from mechanical impact. They had base breaks, restored with inserts of fresh wood, which do not have any finishing in this regard.

The chair seat was devoid of rattan. On top, it was completely covered with a layer of unprofessional bronze paintwork of such thickness that it was not possible to consider the author's decorative finish at all. Even the presence of soil or its absence under the bronzing could only be assumed.

The frame of the chair had a decorative finish in the form of gilding on varnish. The left and right front legs of the chair, glued to the frame, were decorated with carvings in the small roses form with leaves in the upper and lower parts. The joints of the legs with the frame did not match the pattern. By the nature of the finishing of the chair legs, it could be assumed that these were scattered parts of the same set at the time of manufacture since they were lacquered gilding according to levkas. The state of preservation of the left leg was much better than that of the right. On the finish layer of the right leg in its upper part, the layers of stratification of the base wood and the loss of the levkas were visible, covered with an uneven layer of shellac varnish reddened by time.

The lower parts of all four legs were cut with deep scratches and dents, both on the levkas and the areas of bare wood of the base. In the middle and lower parts, they were so heavily soiled with some dense black substance that had penetrated deeply into the surface of the decorative trim and the base of the wood so that the gilding under it was not visible at all.

The losses of the ground with the finishing were mechanical. Especially strong losses and damage to the ground were on the legs, back and seat of the chair. The state of the ground-levkas preservation was regarded as an emergency and required serious conservation with elements of its local restoration. As a decorative finish on the subject was previously used decorative gilding of several types. 
The state of the decorative finish of the chair was severe: almost the entire surface was distorted by strong persistent surface contamination of various nature and domestic nature: dust, dirt, as it turned out later, and shoe polish.

After clearing the bronze paintwork, an even greater number of scuffs and losses of gilding on all the details of the object was revealed.

Thus, with a detailed visual study of the subject of restoration, it was possible to establish the characteristic distortions of the decoration and destruction of this monument, to understand the nature of the origin of the layers of renovation, to assess the scope of the upcoming works and their sequence to return the object to its aesthetic appearance.

\section{Drawing up a restoration programme based on the findings of visual analysis}

The chair was presented to the workshop on the restoration of DAA objects, as a work of 19th-century garden furniture. However, it was not the 19th-century monument because it was an object adapted as a result of the repair only for utilitarian use. It was also confirmed by the severe condition of the various finishes of the chair, which had undergone severe domestic use in the previous time. These circumstances characterized the piece of furniture as never before found in a museum exhibition. In addition, the reconstruction of the decorative decoration in the author's manner, although it was previously created and decorated by many artists, was only partially possible, taking into account the technologies of individual fragments of the chair. With the help of several gilding techniques, the chair could be brought to an aesthetic and expositional appearance.

General conclusion about the state of preservation of the object that was received for restoration. The chair was in poor condition and needed a comprehensive restoration, as there were:

1. Loss of rattan on the seat.

2. Unstable surface contamination of the household plan.

3. Strong persistent diverse surface contamination.

4. Local loss of soil-levkas.

5. Loss of decorative gilding of different types.

6. Distortions of the author's chair decoration in the form of bronzing and imitation of gilding with Dutch metal.

Based on the identified defects, a program of restoration measures was drawn up, which consisted of the following:

1. Removal of unstable surface dirt. 
2. Removal of strong persistent surface contaminants.

3. Removal of imitation gilding by bronzing.

4. Conservation of the author's levkas.

5. Reconstruction of local losses of the ground-levkas.

6. Local reconstruction of gilding on the poliment.

7. Reconstruction of local losses of gilding on an oil binder.

8. Re-creation of imitation gilt Dutch metal on the back of the chair back.

9. Applying protective films to the recreated gilding on an oil binder.

10. Applying protective films to the areas of imitation gilding with Dutch metal.

11. Toning of the restoration gilt to match the colour of the preserved object.

12. Recreating the rattan on the seat.

This programme was approved at a meeting of the restoration council, after which the restoration activities began.

\section{Conservation and restoration of garden chair decoration}

The removal of unstable surface dirt realized by a soft brush and a vacuum cleaner with extreme care, so as not to lose the particles of the emergency levkas.

The removal of strong persistent surface contaminants realized in several stages. Various materials and methods were used for this purpose. After activating the surface of the working area with pure ethyl alcohol with a small squirrel brush and weathering the smell of alcohol after about 40 minutes, mechanical cleaning of the shoe polish and dirt accumulations clots with a wooden stack was performed with extreme care.

A day later, these areas were further cleaned of dirt with a semi-dry foam of baby soap using a soft bristle brush. After a short exposure of 10-15 minutes, the soap foam was removed using small cotton wool swabs, lightly moistened with distilled water and well wrung out. Tampons were replaced with new ones as they became dirty. During this operation, it was necessary to monitor the condition of the gilding surface to prevent the loss of decorative historical finishes.

The imitation gilding was removed by bronzing on the local areas of the chair legs and seat with a mixture of organic solvents: alcohol + pinene (1:1) using cotton swabs, which were often replaced with fresh ones as they became dirty.

On the seat, the removal of solid bronze paintwork was carried out in separate small areas with the help of cotton wool compresses moistened in DMS (dimethyl sulfoxide). The exposure time was from 45 minutes to 1 hour. Then the softened and swollen colourful film of the late coating was removed on the splinter with cotton swabs moistened in acetone. If necessary, a second cotton compress was 
placed, moistened with a mixture of solvents pinene+ ethyl alcohol (1:1) for 15-20 minutes. After removing this compress, the seals of the bronze paintwork were removed using micro-tampons of their cotton wool on a dental corner tweezer or toothpick, depending on the size of the working area, until the paintwork was completely removed from the surface. If it is necessary, additional sampling of individual places realized by an eye scalpel with great care not to damage the surface of the soil and finishing particles.

Preservation (strengthening) of the author's levkas on the back of the chair on the decorative element of the bow was performed with natural honey-rabbit glue with the antiseptic Katamin A-B with water solutions of $5 \%, 7 \%, 10 \%$ concentration sequentially. In places of local losses of the author's levkas to the base and along the cracks of the craquelure with the help of bristle brushes, sizing was also performed with warm $\left(+40^{\circ} \mathrm{C}\right)$ aqueous solutions of honey-rabbit glue: sequentially: $5 \%, 7 \%, 10 \%$ with natural drying of each layer for $15-20$ minutes. After the "drying up" of the author's levkas, the soil was laid. The work was carried out through a fluoroplastics film, first with thick cotton swabs, and then with a warm fluoroplastic spatula heated in hot water to $+40 \ldots+45^{\circ} \mathrm{C}$. The number of impregnations of the soil with the adhesive solution was determined individually on each site depending on the nature of the damage, their number was from 1 to 3 applications.

In the presence of local areas of soil detachment from the base, as well as soil lagging along the boundaries of losses, glueing with a warm aqueous solution of the same glue of $10 \%$ concentration was performed by injection, followed by padding with cotton swabs moistened with distilled water and well wrung out.

Before injection, the areas with soil detachment were wetted with 96 o ethyl alcohol and injected with a syringe through cracks and breaks in the levkas soil to activate the surface of the working area. After saturation of the soil with the adhesive solution by injection, the soil was laid in about 15-20 minutes by pressing it to the base with a cotton swab through the fluoroplastics film. Then further laying realized by a warm fluoroplastic spatula (up to $+40^{\circ} \mathrm{C}$ ) until the soil was completely fixed to the base with constant monitoring of the surface of the restored area.

The reconstruction of the local losses of the ground-levkas realized within the boundaries of its losses to the base (the top of the back, the rollers on the back, the bow, the rollers on the front of the 4 legs, the seat, the king) after the side local strengthening by three times glueing with natural glue 5\%,7\% and $10 \%$, followed by applying levkas. 
Levkas was prepared in advance from a $10 \%$ aqueous solution of honeyrabbit glue, with the addition of pure ground chalk to a creamy consistency in a ratio of 1:2. It was applied to the base layer by layer with bristle brushes, the levkas temperature was maintained by heating it in a water bath $\left(+40^{\circ} \mathrm{C}\right)$. Each levkas layer was dried for 2.5-3.0 hours. To avoid the levkas influx on the border of the joints of the author's and restoration layers, the surface was levelled with a scalpel carefully. In the first two or three layers of levkas, the deepest cracks and recesses in the ground were masticated. Then the levkas was levelled with a scalpel and then sanded dry with an emery cloth of medium and fine (240 and 320) grain. After that, it was thoroughly dusted with a brush and a vacuum cleaner.

Next, there was a recreation of the gilding on the poliment on the front side of the chair back and front legs. On the surface prepared for the poliment, with the help of squirrel brushes, a divorce was applied: a pre-prepared composition of rotten egg white and distilled water. Then the poliment was applied, diluted with rotten egg white to the working consistency and the desired hiding power. The number of layers of the poliment was determined locally (from 7 to 9 layers), with drying, intermediate combing of the surface with a canvas and thorough dedusting.

Then, on the poliment moistened with vodka, a gold leaf was applied (the weight in the book is $2.5 \mathrm{~g}$ ). After drying the surface of the working area in 40-60 minutes, the gold was polished to an even metallic lustre with agate teeth to obtain the appearance of cast metal. Flickering at the gaps places was performed on the 'fook' or 'vodka' with the same gold. The patches were polished from the centre to the edges not to crush the levkas and spoil the fresh gilding.

The reconstruction of local losses of gilding on the oil binder realized on the areas of the restored restoration levkas on the seat, the king, the lower part of the front legs and the entire surface of the rear legs. Initially, an alcoholic solution of shellac of $15 \%$ concentration was applied to the levkas twice with intermediate drying of the layers for 24 hours. If necessary, the first layer of varnish was sanded with velvety sandpaper No. 1000 and carefully dedusted. Then a gulfarba layer was put to the shellac varnish resulting layer. When a working flake appeared on the oil composition layer after 15-18 hours, a light gold overlay was made (the book weight was 1.25-1.40 g). The gold was cut slightly larger than the place where the gilding was lost, tamponed after the lining with a cotton wool cotton swab and polished with the same swab until a uniform surface was obtained. Flickering of the gaps was done immediately on the 'fook'.

The reconstruction of the gilt Dutch metal imitation on the back of the upper part of the chair back was made based on the fact that during the clearing of the 
surface from the old gulfarba and oxidized Dutch metal, no trace of guilt endings was found there. The backside of the upper part of the chair back was also precoated with a double alcohol shellac varnish of $15 \%$ concentration, after drying which gulfarba was applied. The application of yellow Dutch metal to the prepared surface of the upper part of the chair back realized the next day. Also, as in the previous case, the Dutch metal was lapped to the surface with a cotton swab of medium size and density. Defects were corrected by the 'fook' method. The lining of small stanzas was placed on the defecting places, followed by levelling from the centre to the stanza edges.

The entire surface of the chair's matte decorative finish (except for places with poliment gilding) was covered with a matte solution after sufficient drying for 2-3 weeks.

The matte solution was manufactured from a warm 3-5\% solution of food gelatin in water with the addition of a $10 \%$ solution of sandarac resin in rectified alcohol to obtain a milky colour (the compositions were mixed in a ratio of 1:1) and alcohol extract from saffron in a small amount for toning the solution. The matting solution should be warm when applied $\left(+40^{\circ} \mathrm{C}\right)$, for this purpose, the solution was in a bowl immersed in hot water to avoid thickening and applied with a soft squirrel wide brush without levelling at one time.

The application of protective films to the areas of imitation gilding with Dutch metal realized by applying the transparent varnish tsapon diluted with acetone in a ratio $(1: 1)$ without levelling in one layer with a synthetic brush with a spatula No. 10.

If it was necessary, the matting composition was tinted with different alcohol extracts to give it a certain shade, depending on the colour of the working area in comparison with the neighbouring one. In this case, it was additionally tinted with different alcohol extracts. For this purpose, alcoholic solutions of the "Dragon's Blood" resin, extracts from the bark of buckthorn and oak were used, which were introduced, if necessary, in a small amount of matting composition to give it the desired shade in each particular case.

The application of a matte solution to the areas of matte gilding realized to fix the tinting and give the gilding on the varnish a velvety matte surface, the desired shade of colour, as well as to protect the finish from the effects of persistent surface contamination during the subsequent operation of the chair.

The rattan recreation on the seat was made after performing a full range of work on the chair's trim restoration. 
Thus, as a result of the complex restoration measures carried out following the restoration task, the garden chair was given an aesthetic appearance with the observance and application of the necessary measures of soil conservation-levkas, glossy restoration and matte gilding on the object's front side within the boundaries of its losses, as well as gilding imitation with Dutch metal on the backside of the chair back and protection of this coating from oxidation during its further use as a museum piece of garden furniture.

\section{Conclusion}

During the complex of conservation and restoration works on the object, it was possible to preserve the levkas soil using natural materials, correctly remove late non-professional layers in the bronze paint form using organic solvents and baby soap foam for this purpose in the areas of historical gilding varnish.

When removing hard-to-remove persistent surface dirt from the surface of the lacquer gilt on the chair legs, a completely strange at first glance type of dirt was found - shoe polish, as a trace of the existence of the object and improper handling of the chair in the past. For many years of practical activity of the master, this was the first time, but the right decision came in the course of performing this operation.

It was possible to correct the numerous defects of the soil, select the compositions' formulation to perform technologically necessary operations for gilding on the poliment and matte gilding on the gulfarba and perform them within the limits of the existing losses.

A very important work, as it seems to the master, was the work on the selection of shades of matting and toning compositions for the new gilding with the use of extracts and infusions from resins, roots and bark of plants, which allowed to correctly extinguish the shine of the restoration gilding on the lacquer binder, as well as to solve issues related to the application of protective coatings on the newly made Dutch metals on the back of the upper part of the chair back.

As a result of the comprehensive restoration of the garden chair with rattan, the master restorer acquired a certain useful theoretical knowledge on the topic and practical experience of working with the subject of decorative and applied art, which had its own, characteristic only for it, features of the technical condition and methods of working with it to return the chair to its aesthetic and exposition appearance.

This work was completed on time and was highly appreciated by the customers. When accepting the work, they were surprised by what they heard and 
saw concerning the restoration subject: those individual features of the subject that they did not notice when writing the original task to restore the chair.

\section{References:}

Alkouf, D. (2016). Restoration of antique furniture. Trans. by Vyacheslav Timofeev. St Petersburg: Symposium. (in Russian)

Antsov, V.L. (1911). Gilding and silvering on wood and metal: A practical guide for amateurs and practitioners to gilding and silvering various wooden and metal things with gold and silver leaf, as well as all kinds of lacquers. (Library "Friend of the Artisan"). Petrograd; Moscow: M. P. Petrov Publishing House. (in Russian)

Fedoseeva, T.S. (1999). Materials for the restoration of paintings and objects of applied art. Moscow: RIO GosNIIR. (in Russian)

Kaznacheyev, K.A. (1890). Gilding and silvering of wooden products: Production of baguettes, cornices, picture frames, etc. Moscow: Library of Artisans. (in Russian)

Kes, D. (1979). Furniture styles. Budapest: Publishing House of the Hungarian Academy of Sciences.

Lermontov, V. (1890). Gilding and silvering of wooden products. Moscow. (in Russian)

Nikitin, M.K., Melnikova, E.P. (1990). Chemistry in restoration. Leningrad. (in Russian)

Nikolaev, A.S. (1949). Works of the gilder. Leningrad, Moscow. (in Russian)

Revo, A.Y. (1947). Painting and artistic and decorative works. Moscow: Trudrezervizdat. (in Russian)

Schmidt, L.P. (1903). Gilding, silvering and bronzing on wood: Complete. bome factory production of baguette for cornices, picture frames, etc.: A guide for carpenters, frame makers, furniture makers, prof. masters and amateurs: In 4 parts. Moscow: N.N. Bulgakov's Printing House. (in Russian)

Sokolova, T.M. (1990). The ornament is the handwriting of the era. Leningrad. (in Russian) 


\section{Appendix}
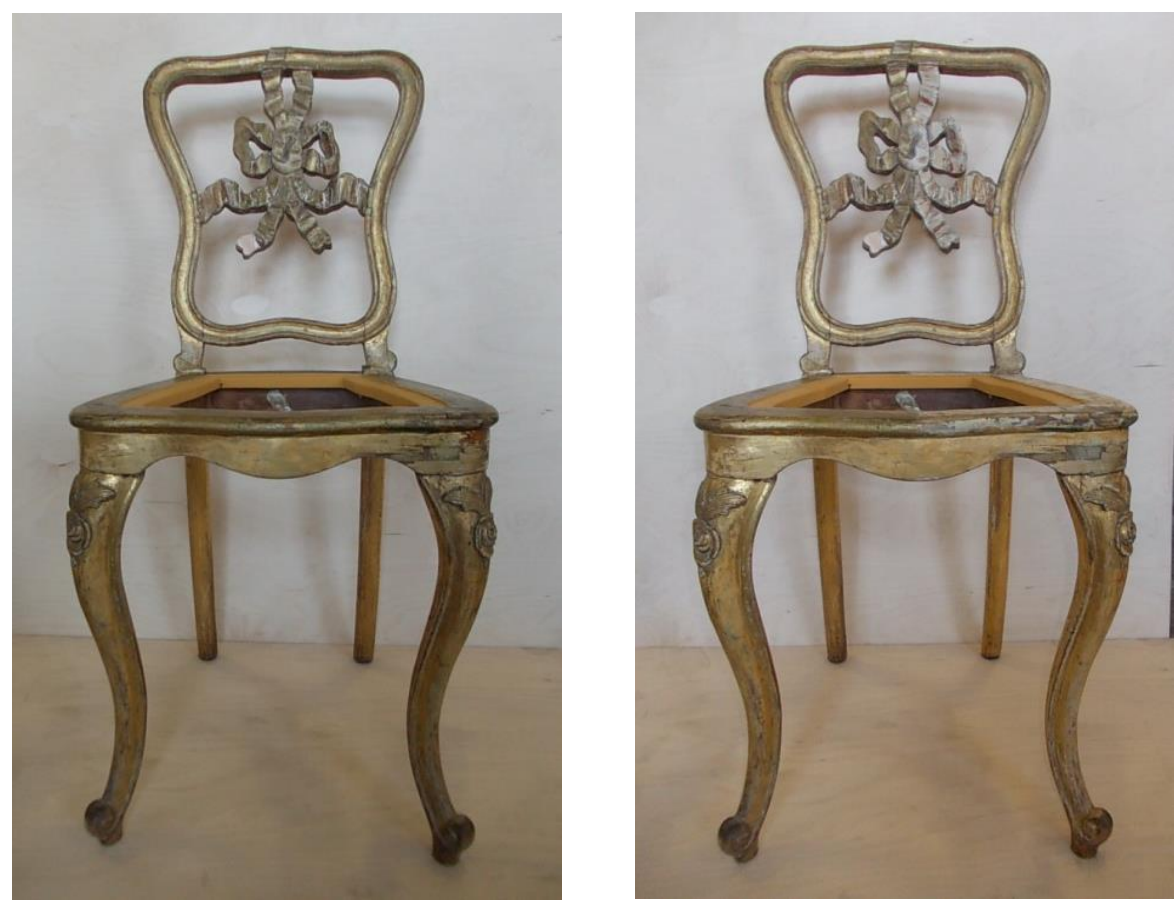

Figures 1-2. General view of the front side of the table before restoration in the process of half-clearing of late layers and persistent surface dirt
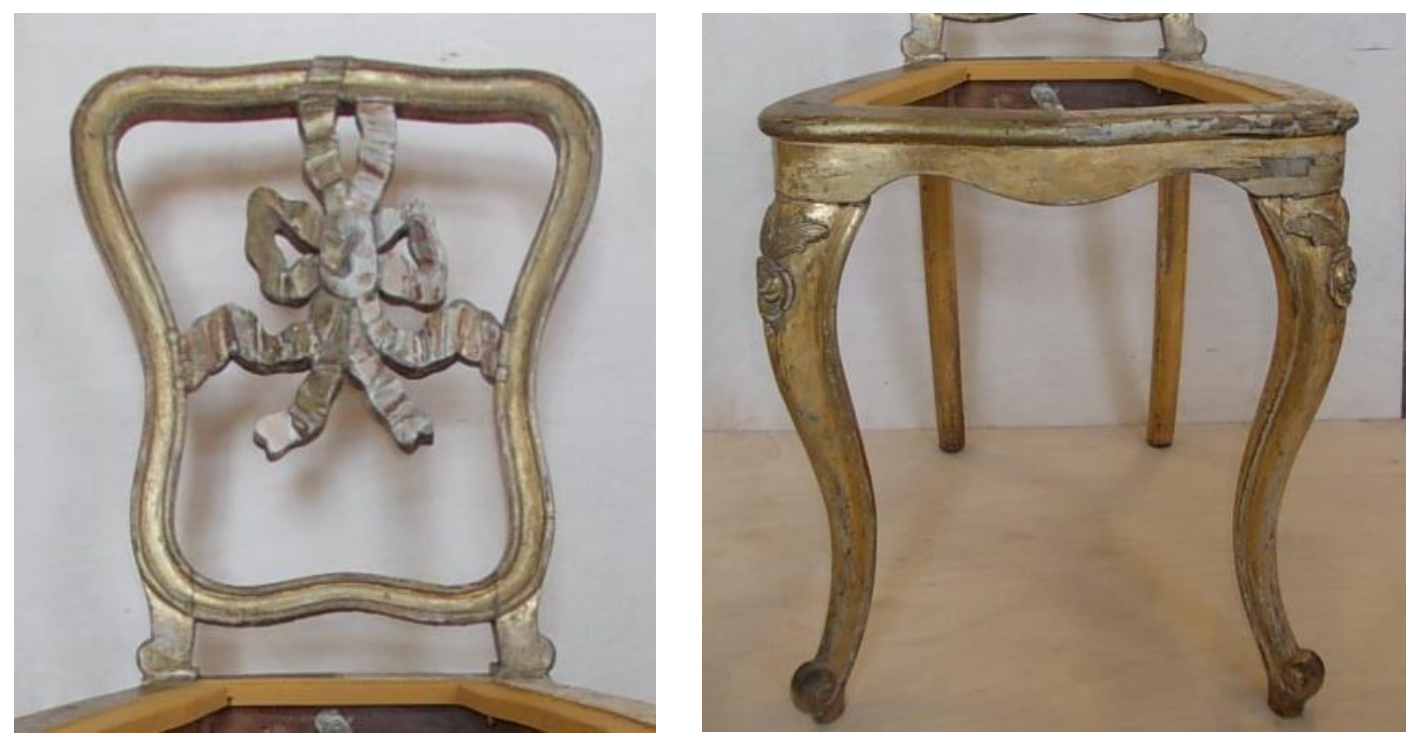

Figures 3-4. Fragments of the front side of the chair (back, frame, and legs) in the process of half-clearing of late layers and persistent surface dirt 

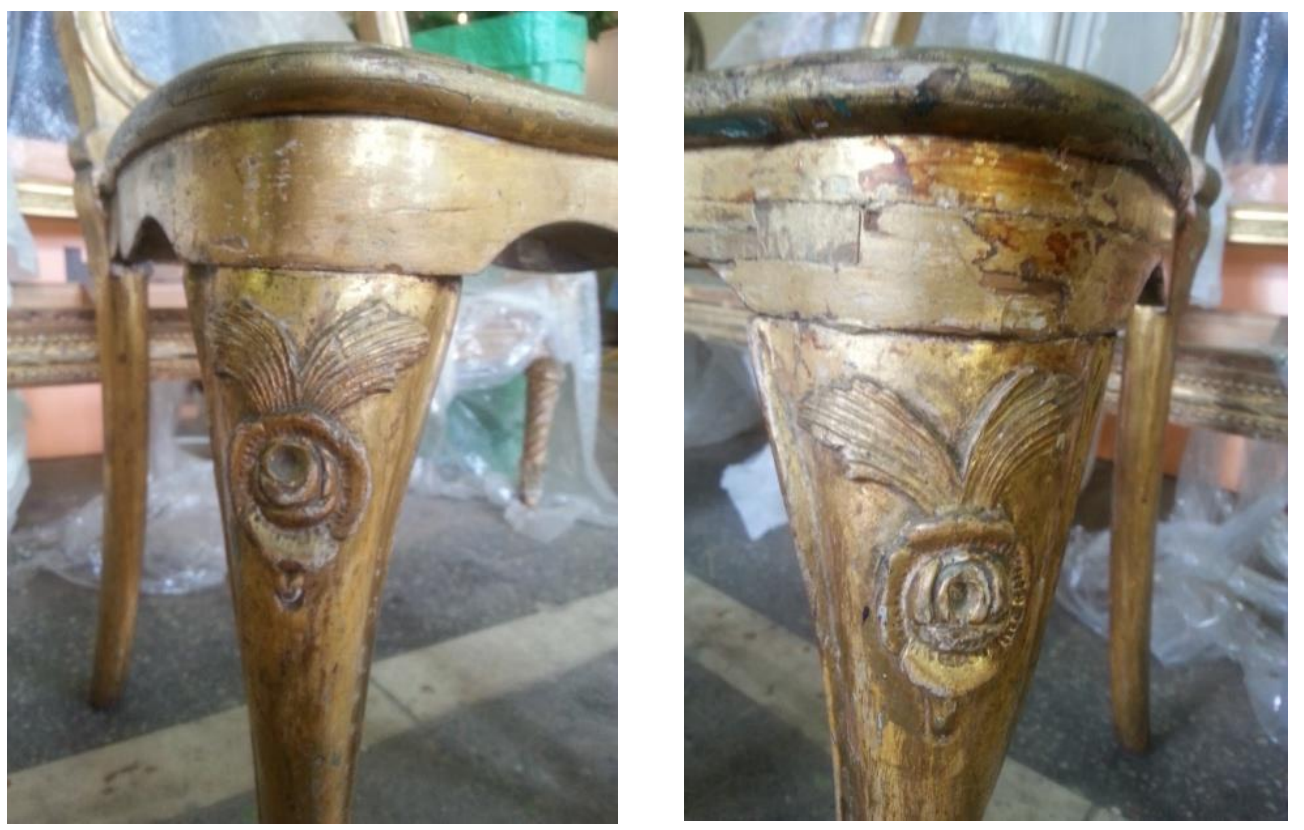

Figures 5-6. Fragments of the front side of the chair (upper parts of the left and right legs) before the restoration

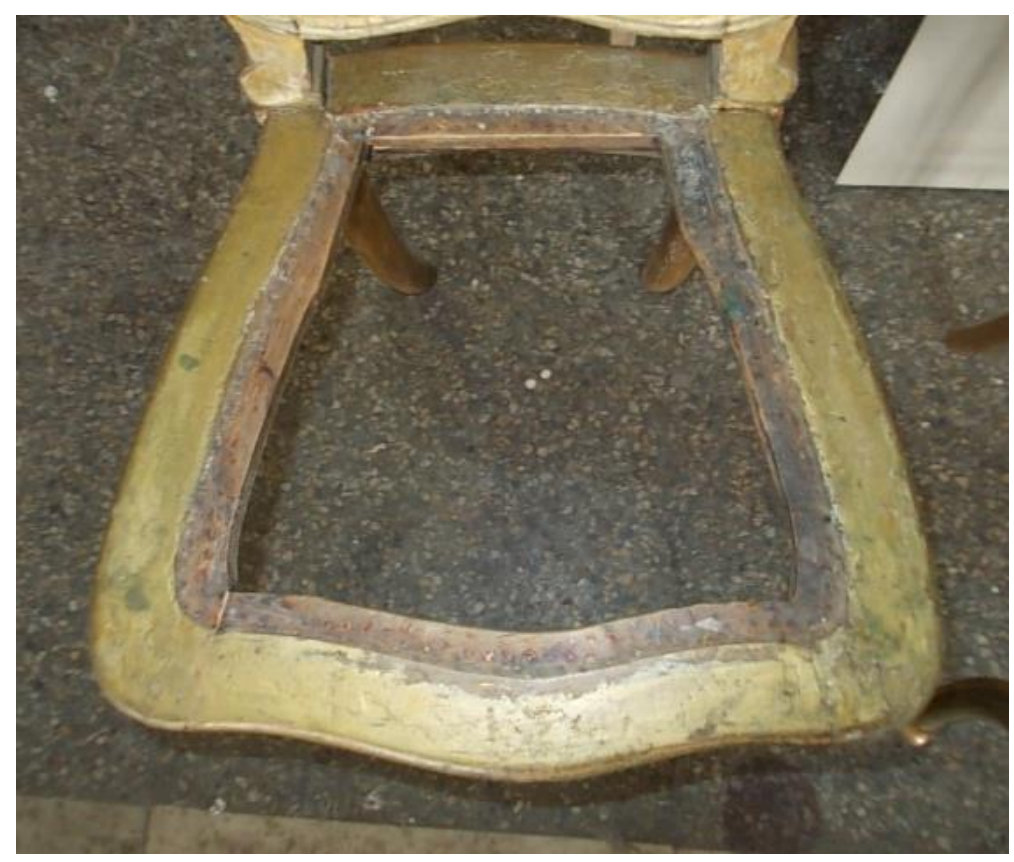

Figure 7. Fragment of the front side of the chair (seat) before restoration with strong solid late bronze paintwork 


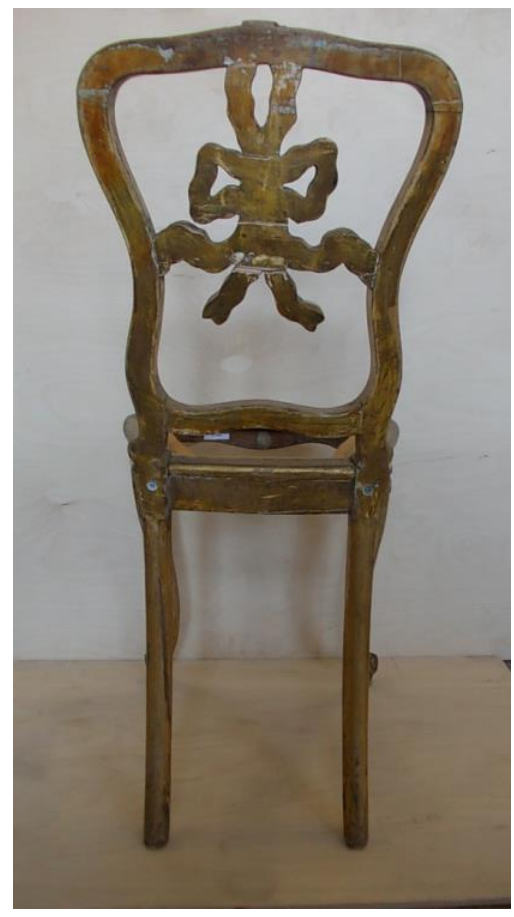

Figure 8 . The back of the chair (back) before restoration
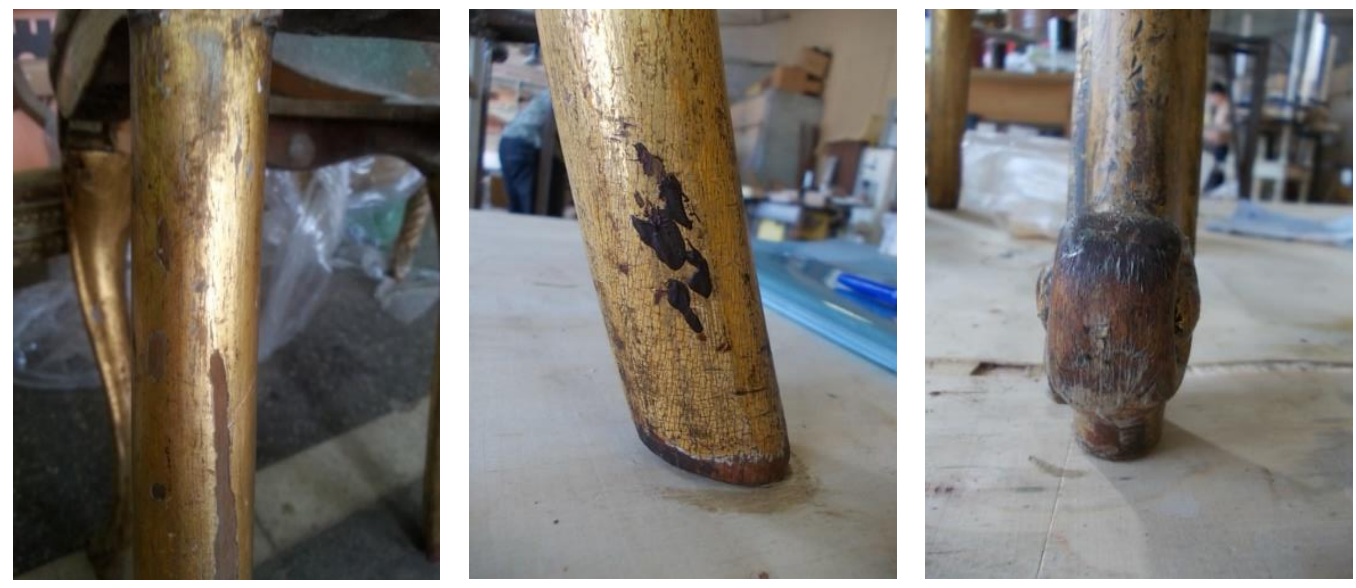

Figures 9-11. Fragments of chair legs with loss of soil with finishing and heavy persistent dirt 

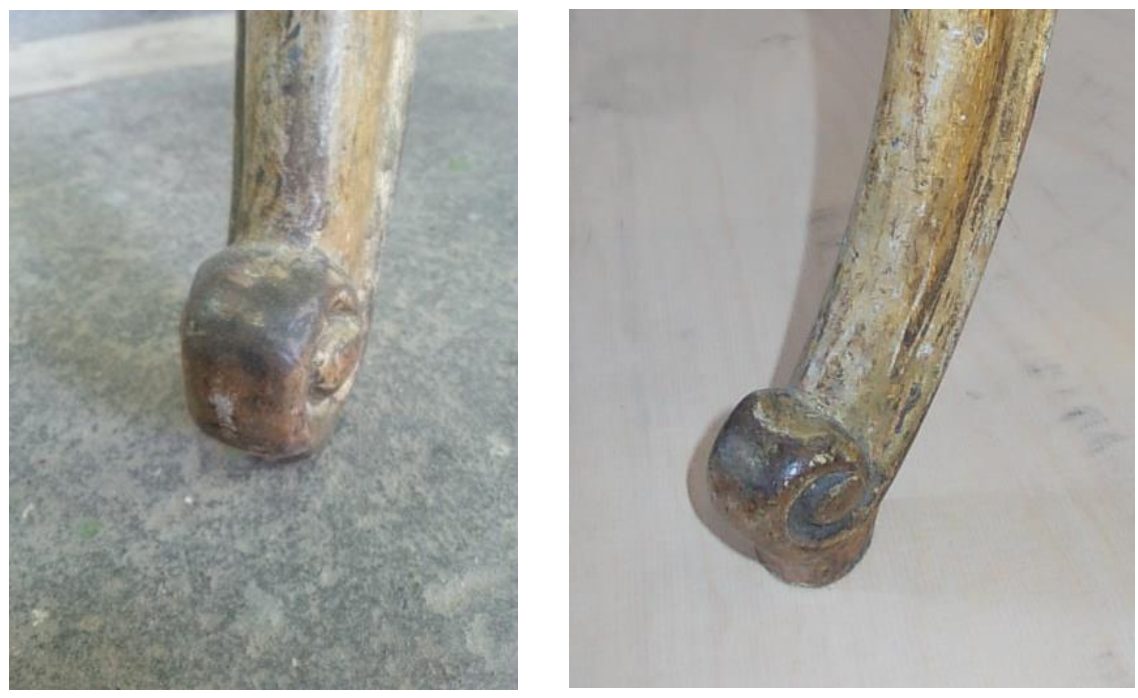

Figures 12-13. Fragments of chair legs with loss of soil with finishing and heavy dirt
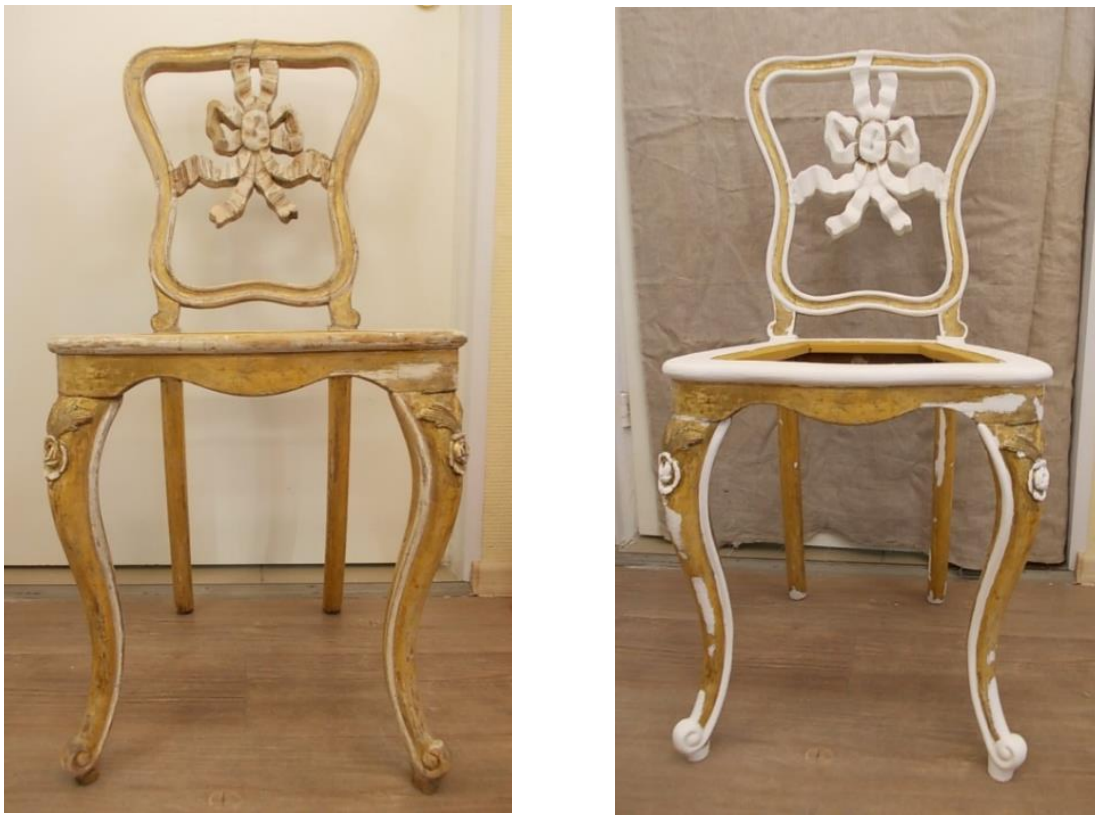

Figures 14-15. General view of the front side of the chair in the process of restoration after clearing of late layers and local reconstruction of the loss of soil-levkas 

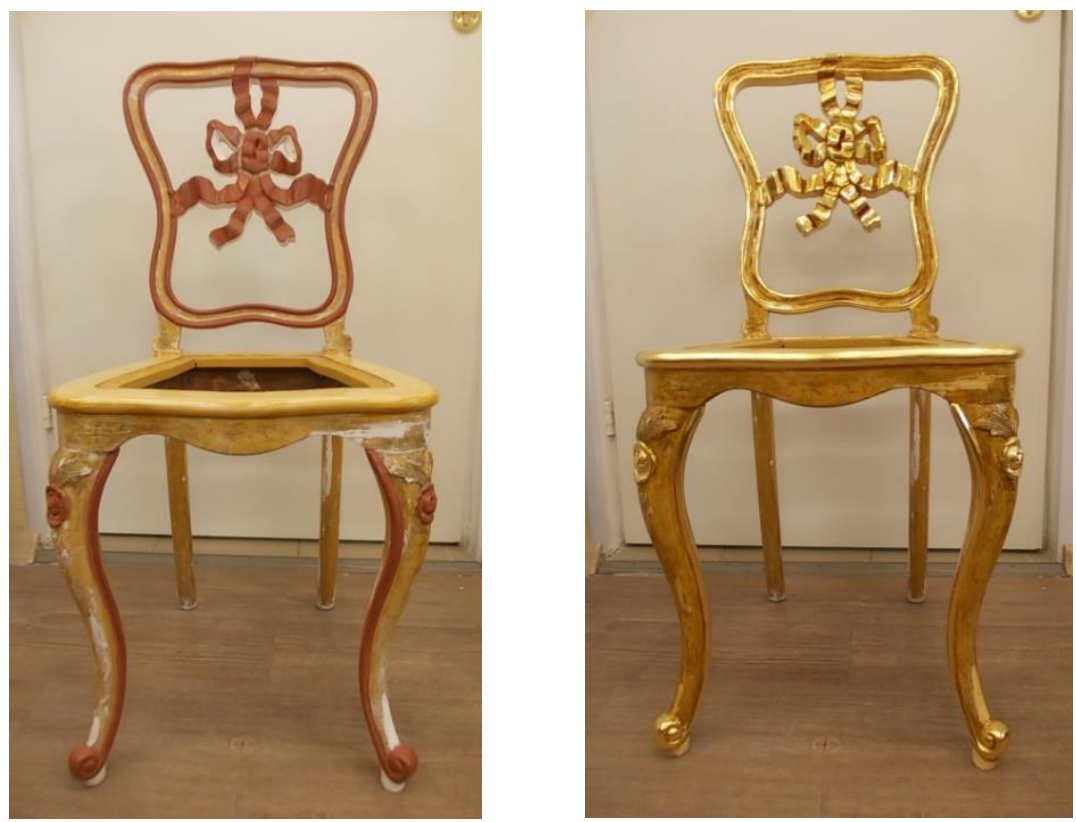

Figures 16-17. General view of the front side of the chair in the process of restoration - application of primer-poliment and in the process of gilding on the poliment

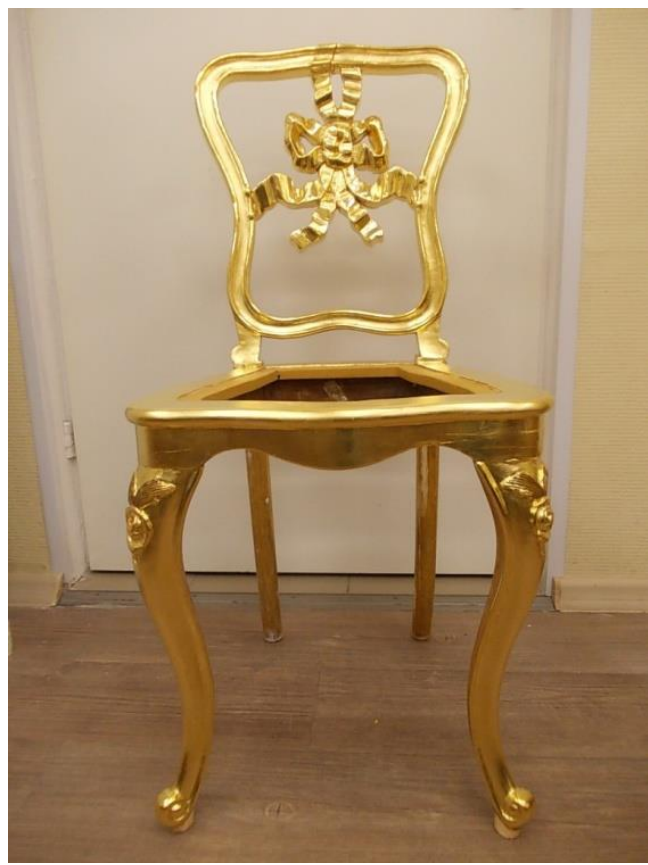

Figure 18. General view of the front side of the chair after performing all types of gilding 

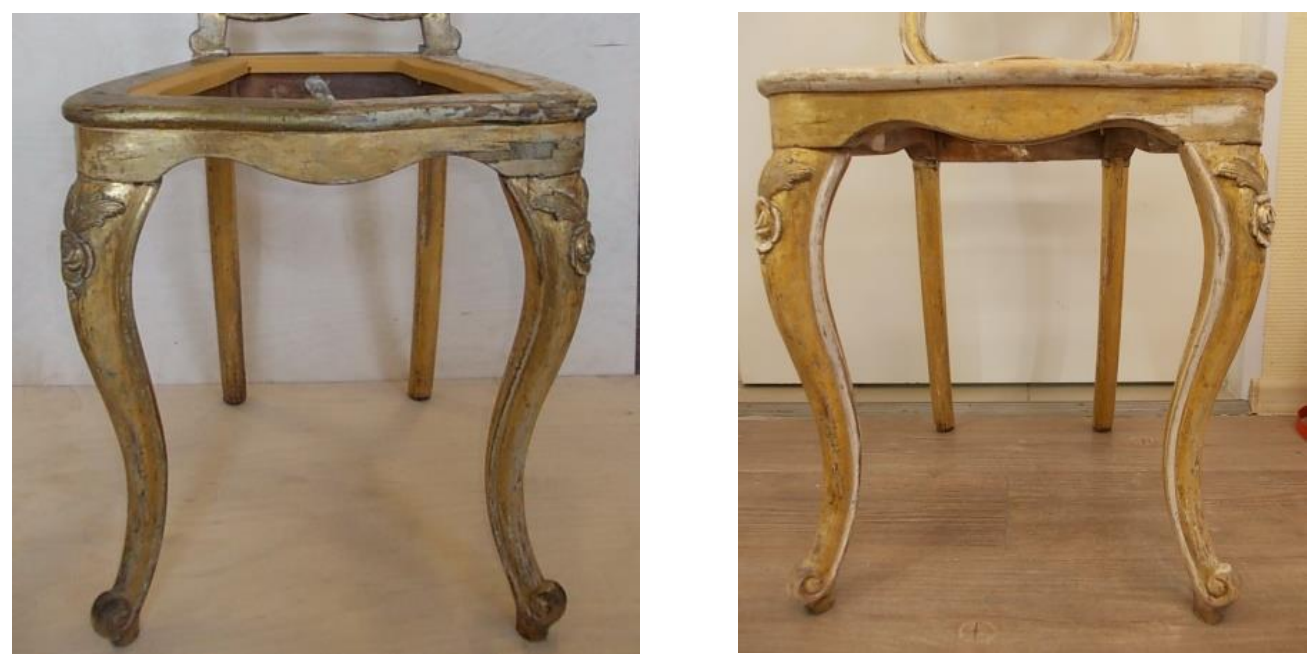

Figures 19-20. Fragments of the front side of the table (frame and legs) in the process of half-clearing of late layers and full clearing of persistent surface dirt
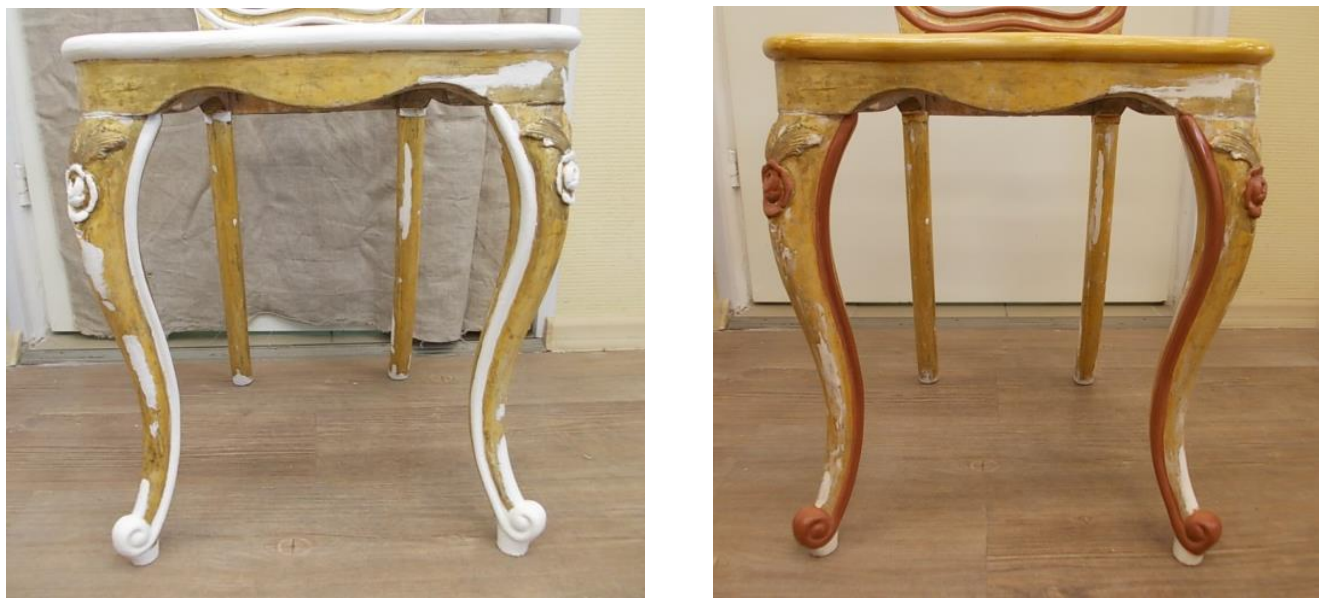

Figures 21-22. Fragments of the front side of the chair (frame and legs) in the process of local replenishment of the loss of levkas and the application of the poliment to perform glossy gilding on the poliment 

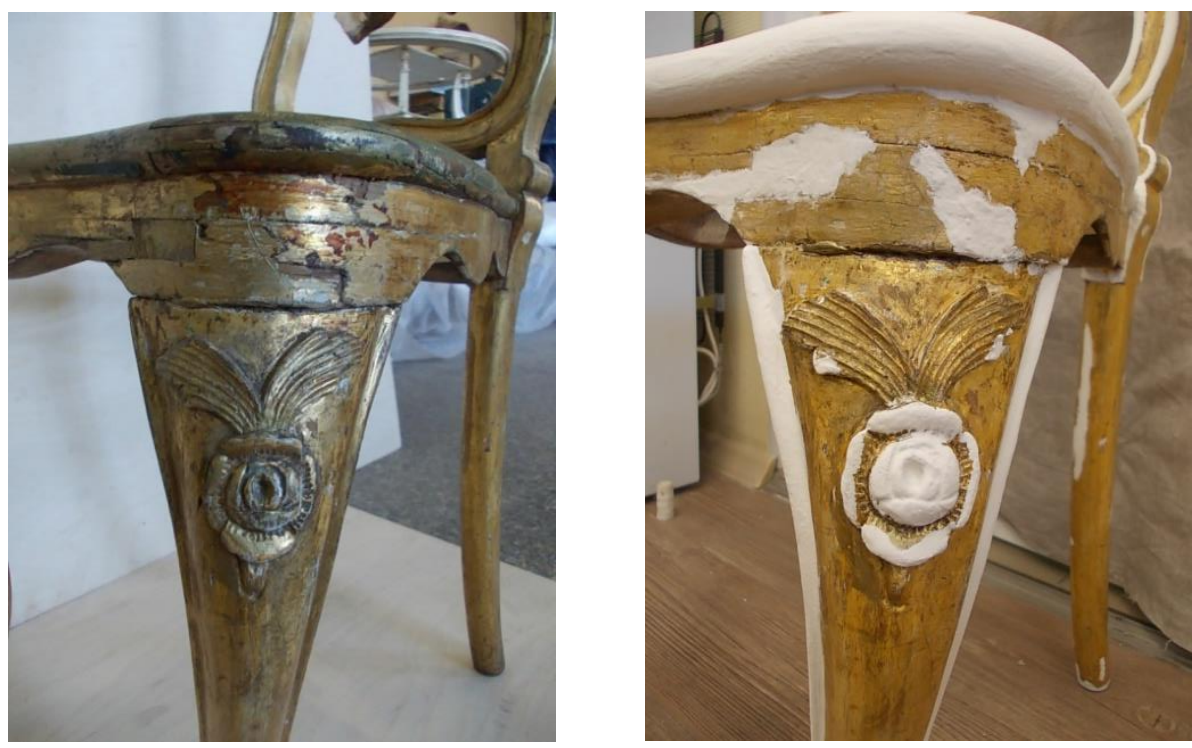

Figures 23-24. A fragment of a chair (top of the right leg) before restoration and after removal of uneven reddened shellac varnish and local replenishment of the loss of levkas
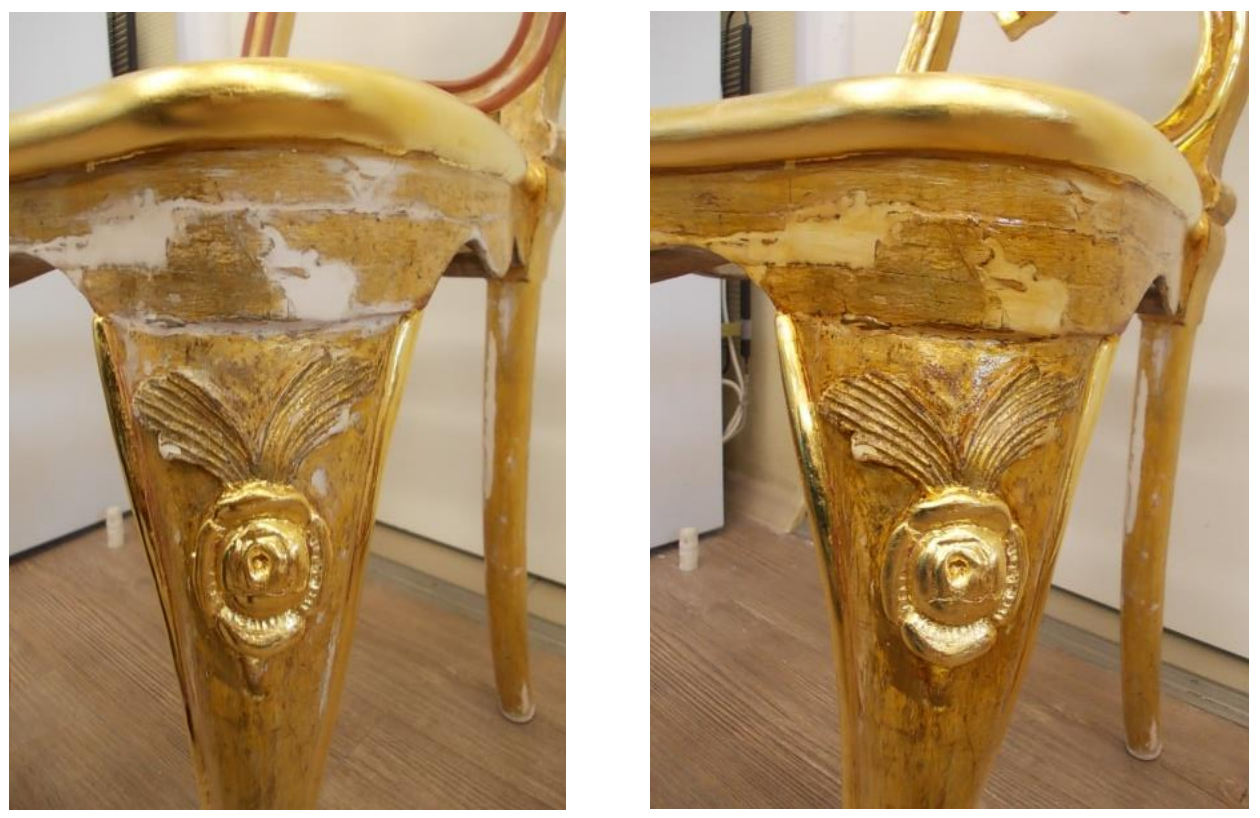

Figures 25-26. A fragment of a chair (the top of the right leg) in the process of glossy gilding on the flower and rollers and applying shellac varnish on the recreated levkas before matte gilding 

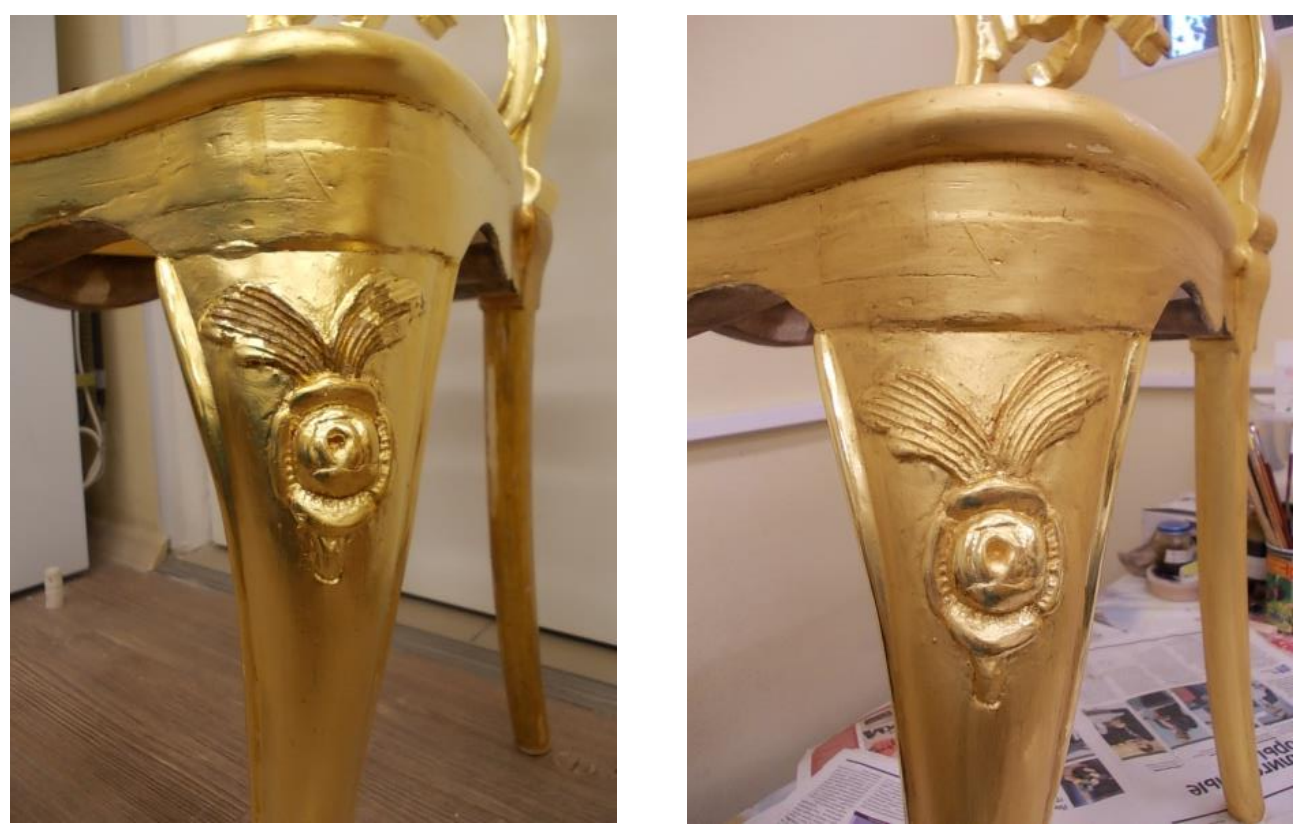

Figures 27-28. A fragment of a chair - the top of the right leg after performing local glossy and matte gilding and applying a matte toning composition to the areas of matte gilding
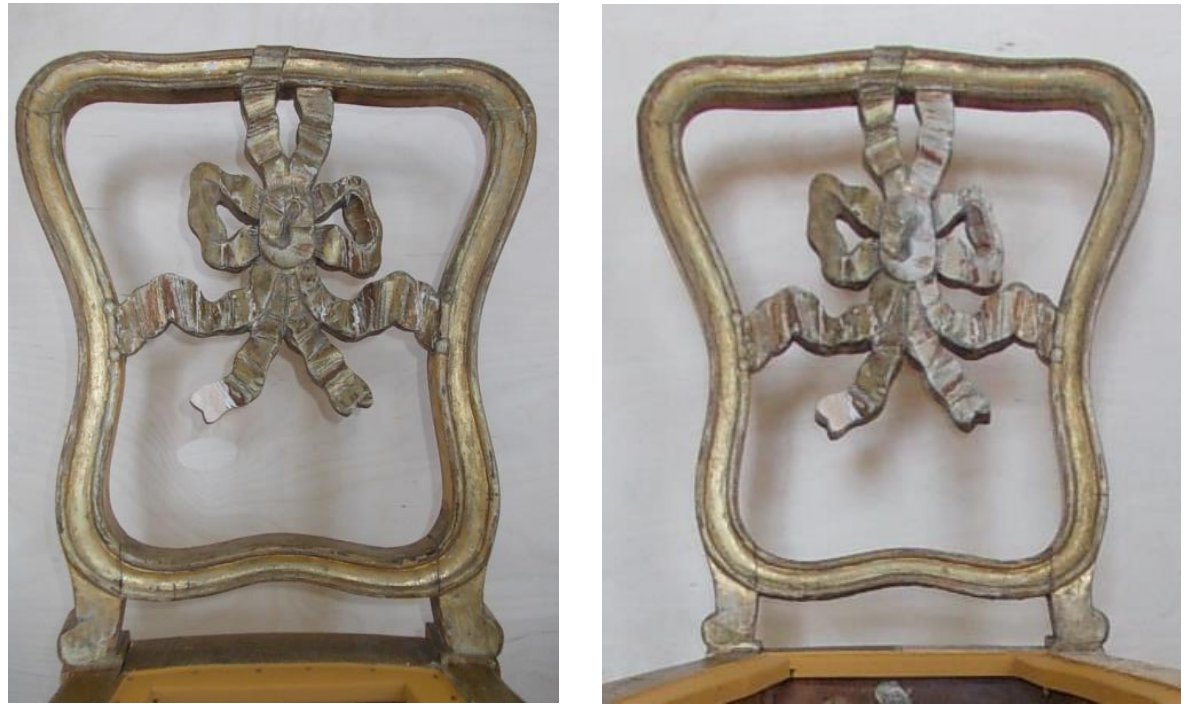

Figures 29-30. A fragment of the chair (front side of the back) before restoration and in the half-clearing of late layers and persistent surface dirt 

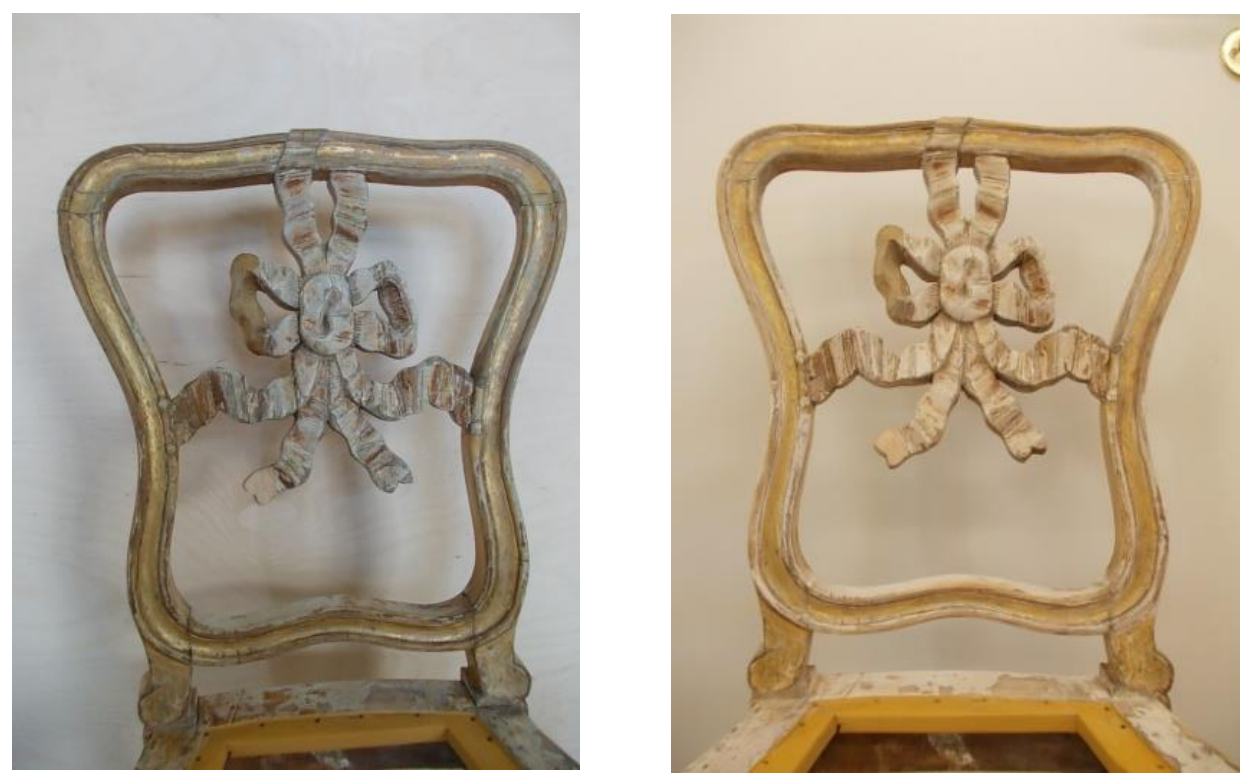

Figures 31-32. A fragment of a chair (front side of the back) in the process of restoration after clearing of late layers and persistent surface dirt
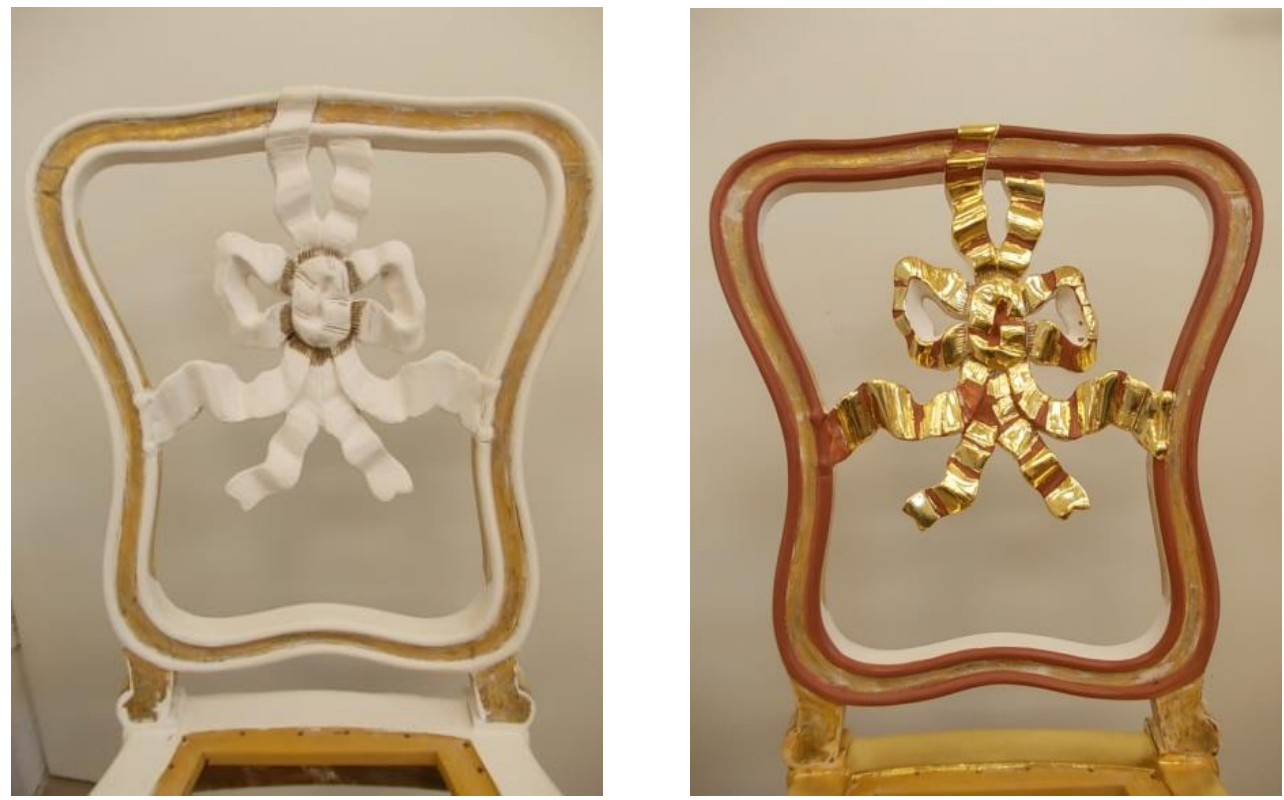

Figures 33-34. A fragment of a chair (front side of the back) in the process of restoration after making up for local losses of the levkas, applying a primerpoliment on the outer perimeter of the back and performing gilding on the poliment on the fragment of bow 

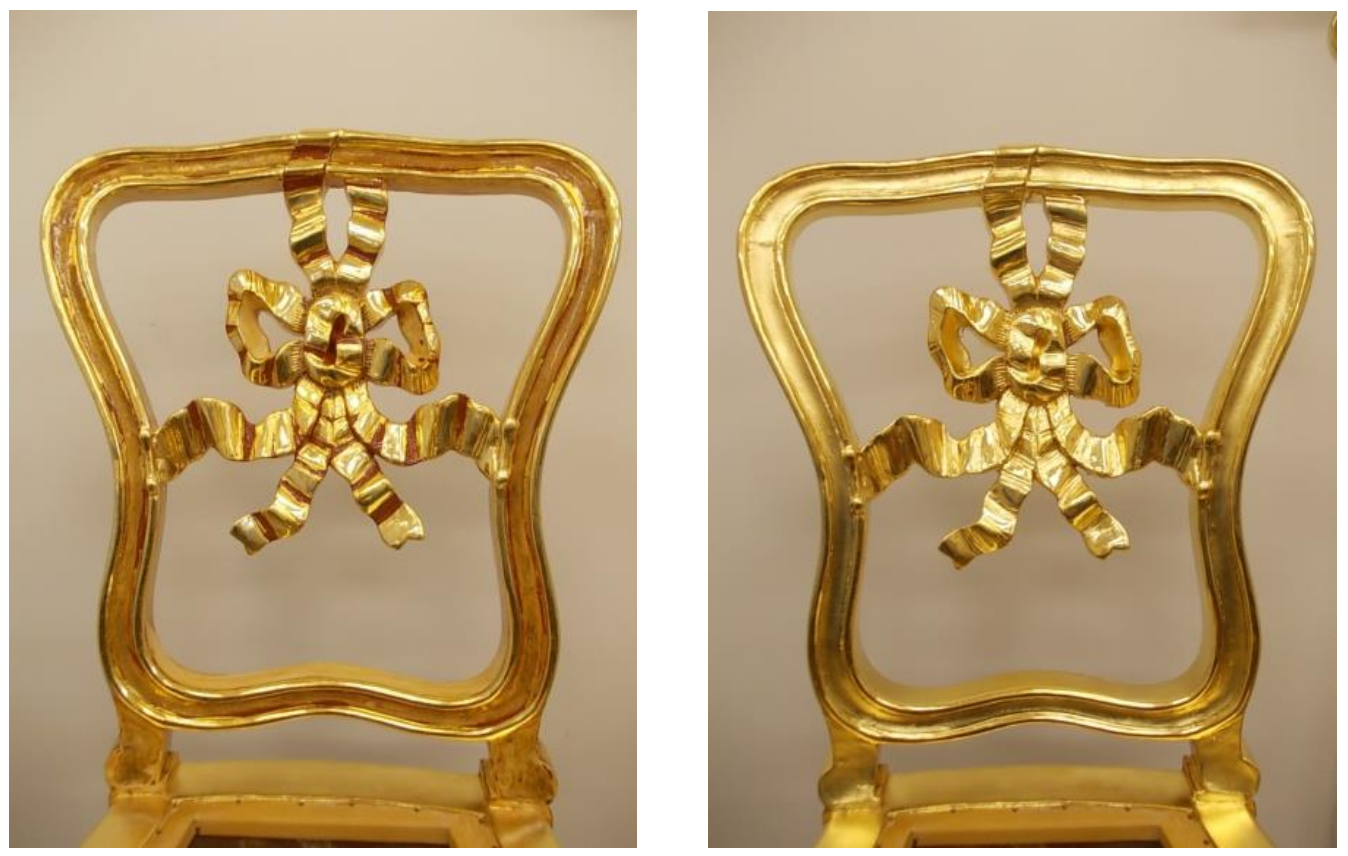

Figures 35-36. A fragment of a chair (front side of the back) in the process of restoration after filling in the local gilding of the back cushions and the bow on the poliment. Matte gilding of the background areas of the chair back on spoons
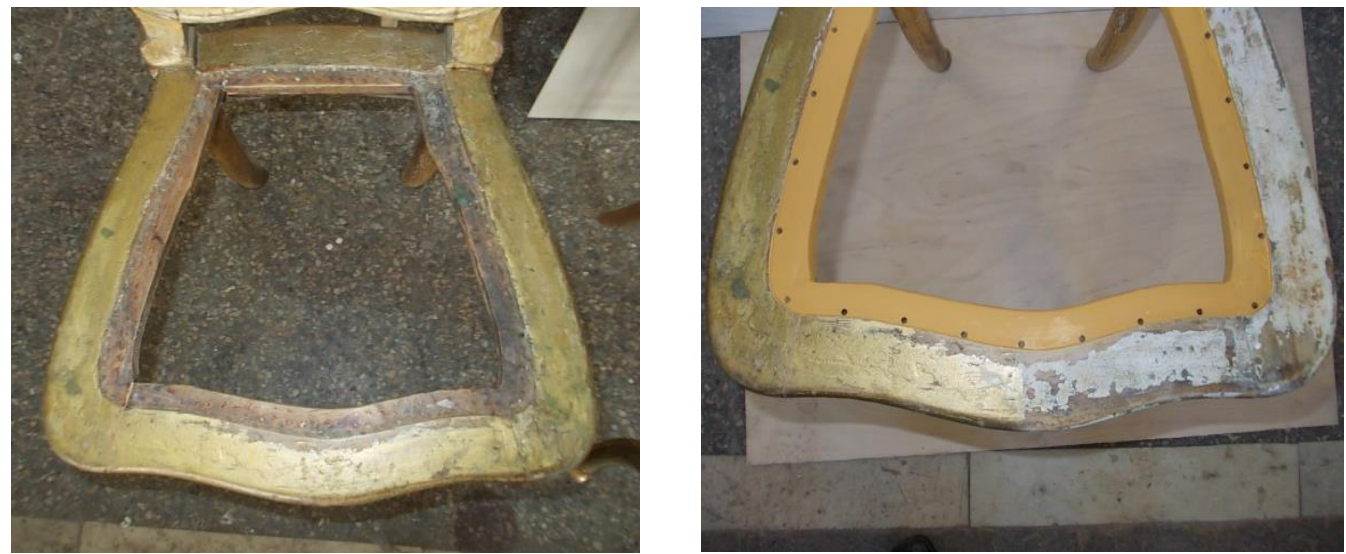

Figures 37-38. A fragment of a chair (seat) before restoration with solid bronze paintwork and half-clearing of late bronze paintwork with revealed loss of groundlevkas 

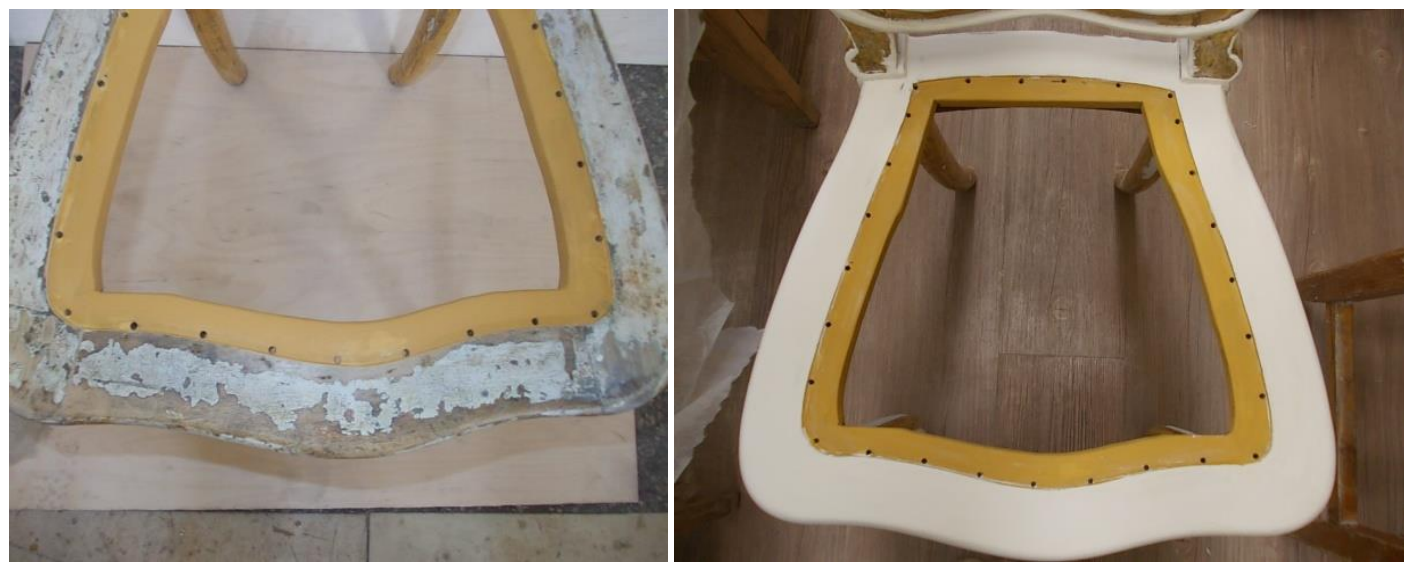

Figures 39-40. A fragment of a chair-seat in the process of restoration-after the removal of solid bronze paintwork with the loss of the ground-levkas
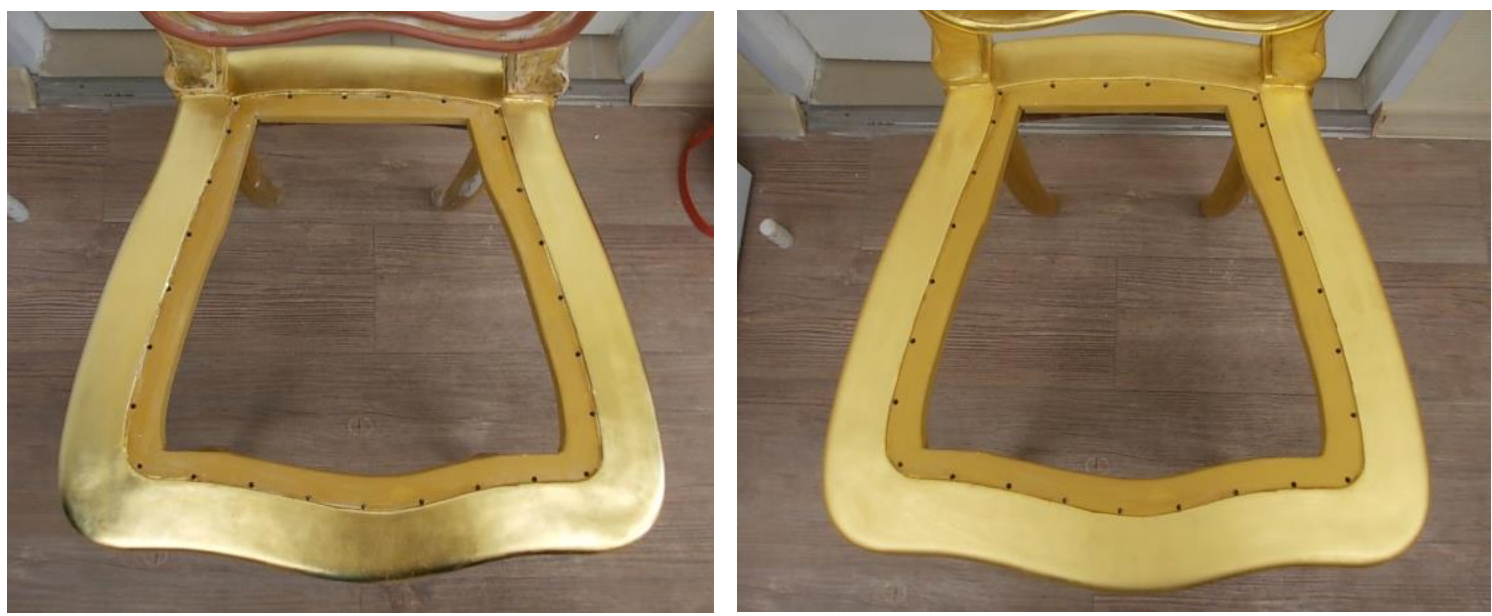

Figures 41-42. A fragment of a chair (seat) in the process of restoration: matt gilding on the codpiece and the process of tinting matt gilding 

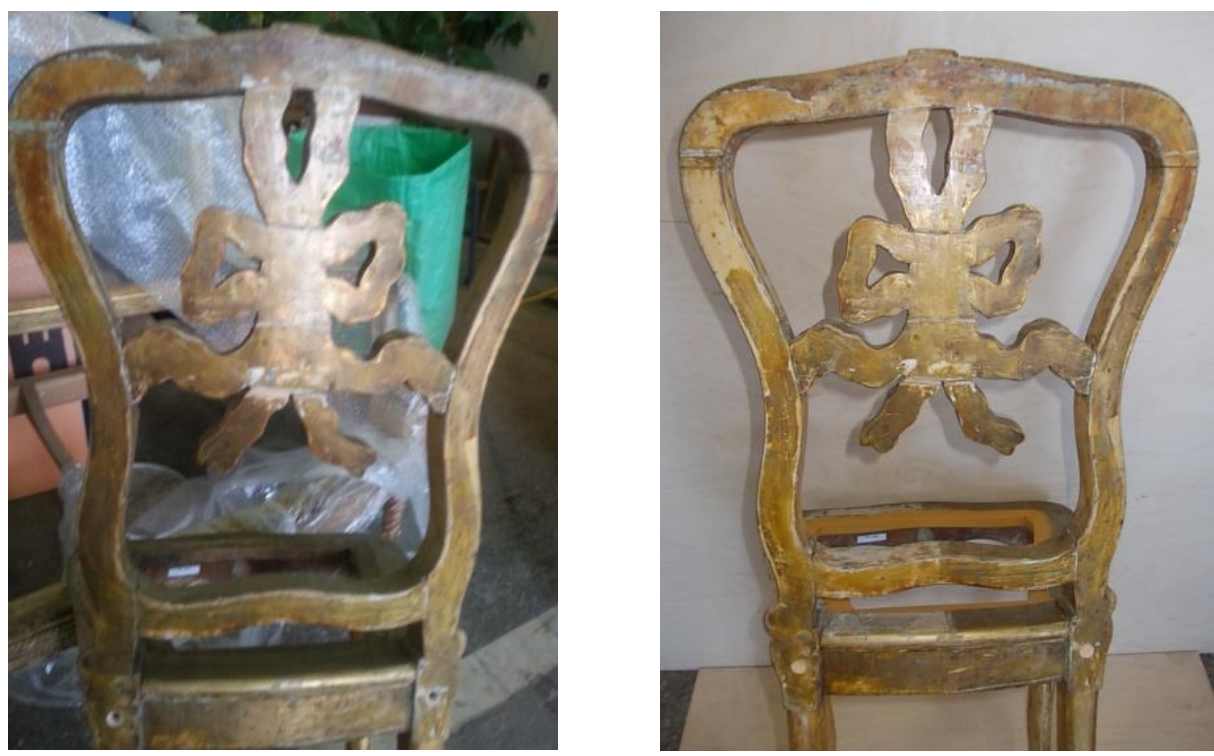

Figures 43-44. A fragment of the back of the chair back before restoration, in the process of removing persistent surface dirt
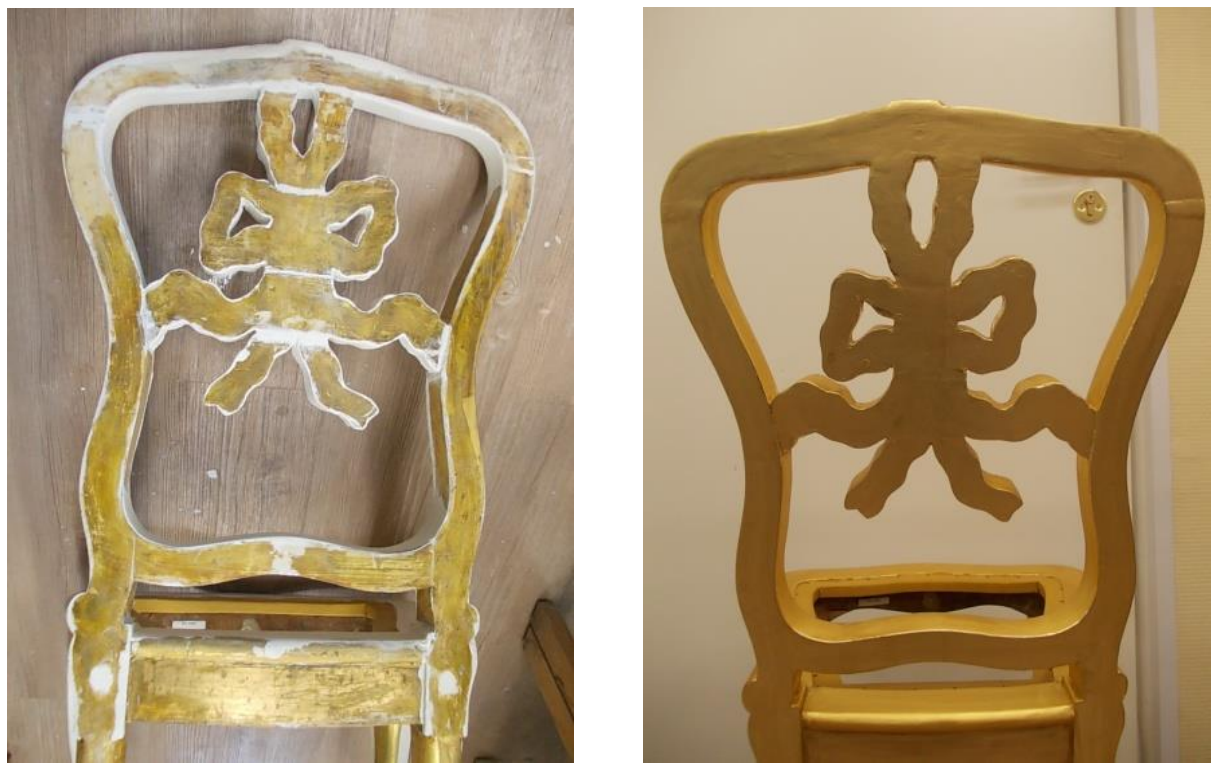

Figures 45-46. A fragment of the back side of the chair back in the process of restoration after removing persistent surface dirt and making up for local losses of the ground-levkas; in the process of recreating the imitation of gilding with Dutch metal 

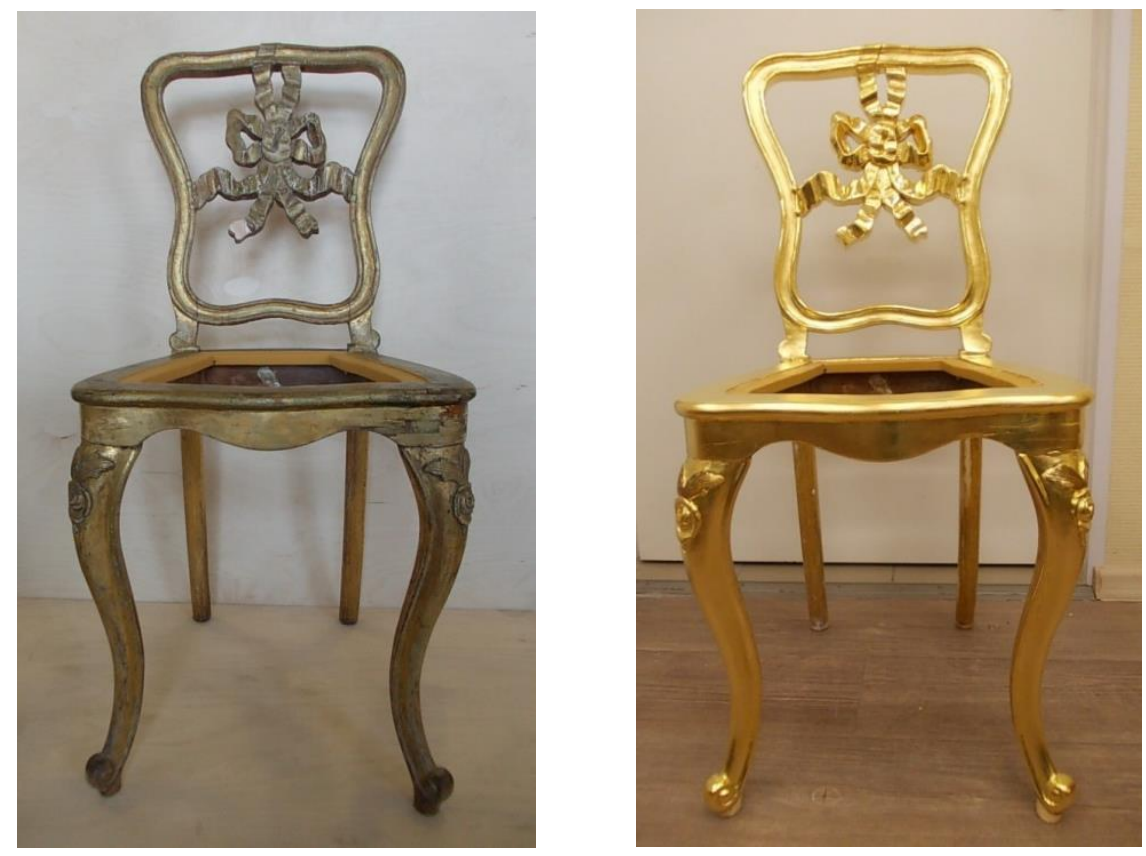

Figures 47-48. The front side of the chair before and after performing a complex of restoration works
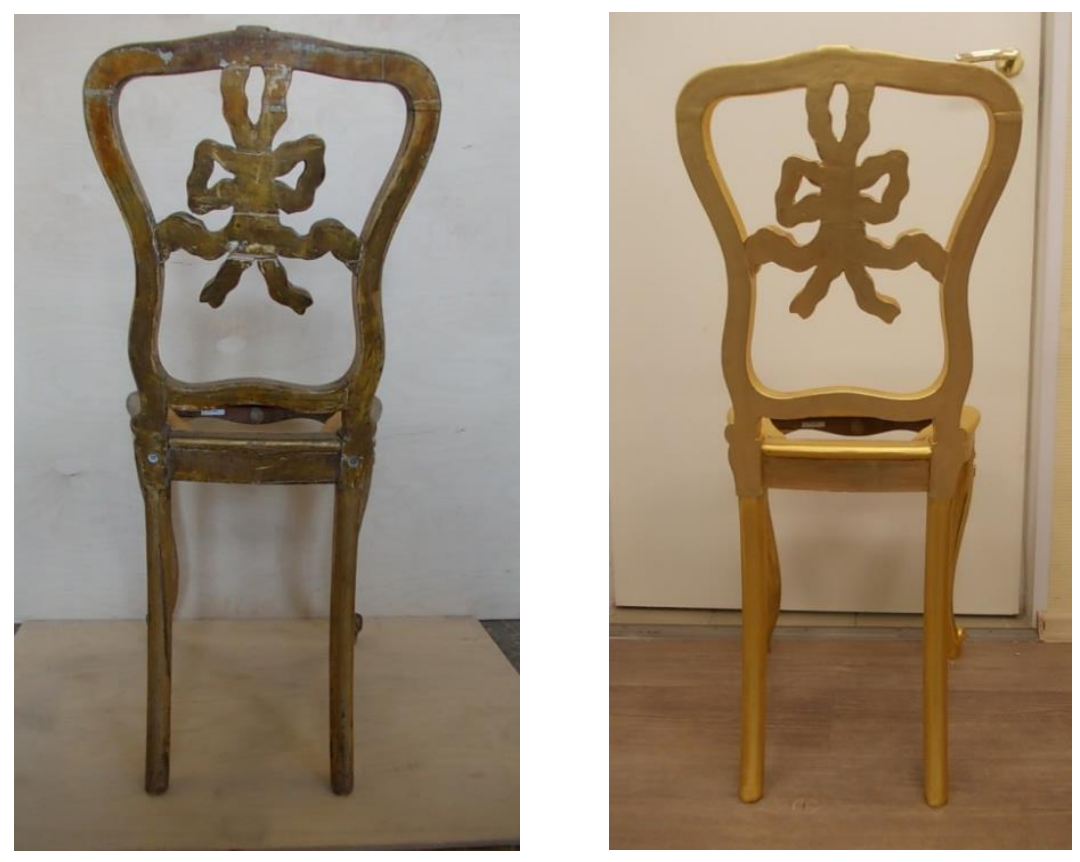

Figures 49-50. The back side of the chair before and after performing a complex of restoration works 